Research Article

\title{
Circulating Cytokines and Lymphocyte Subsets in Patients Who Have Recovered from COVID-19
}

\author{
Hasichaolu, ${ }^{1}$ Xinri Zhang, ${ }^{2}$ Xin $\mathrm{Li}^{3}{ }^{3}$ Xin $\mathrm{Li}^{1},{ }^{1}$ and Dongyan $\mathrm{Li} \mathbb{D}^{2}$ \\ ${ }^{1}$ Department of Laboratory Medicine, First Hospital of Shanxi Medical University, Taiyuan 030001, China \\ ${ }^{2}$ Department of Respiratory and Critical Medicine, First Hospital of Shanxi Medical University, Taiyuan 030001, China \\ ${ }^{3}$ Department of Cardiology, Cardiovascular Hospital of Shanxi Province, China
}

Correspondence should be addressed to Dongyan Li; lidongyan_4639903@outlook.com

Received 22 June 2020; Revised 23 October 2020; Accepted 27 October 2020; Published 27 November 2020

Academic Editor: Saheem Ahmad

Copyright (c) 2020 Hasichaolu et al. This is an open access article distributed under the Creative Commons Attribution License, which permits unrestricted use, distribution, and reproduction in any medium, provided the original work is properly cited.

To investigate the immune status of people who previously had COVID-19 infections, we recruited two-week postrecovery patients and analyzed circulating cytokine and lymphocyte subsets. We measured levels of total lymphocytes, $\mathrm{CD}^{+}{ }^{+} \mathrm{T}$ cells, $\mathrm{CD} 4^{+} \mathrm{T}$ cells, $\mathrm{CD}^{+} \mathrm{T}$ cells, CD19 ${ }^{+} \mathrm{B}$ cells, and $\mathrm{CD}^{+} 6^{+} \mathrm{NK}$ cells and the serum concentrations of interleukin- (IL-) 1, IL-4, IL-6, IL-8, IL-10, transforming growth factor beta (TGF- $\beta$ ), tumor necrosis factor alpha (TNF- $\alpha$ ), and interferon gamma (IFN- $\gamma$ ) by flow cytometry. We found that in most postrecovery patients, levels of total lymphocytes $(66.67 \%), \mathrm{CD}^{+} \mathrm{T}$ cells $(54.55 \%), \mathrm{CD} 4^{+} \mathrm{T}$ cells $(54.55 \%), \mathrm{CD}^{+} \mathrm{T}$ cells $(81.82 \%), \mathrm{CD}^{+} 9^{+} \mathrm{B}$ cells $(69.70 \%)$, and CD56 ${ }^{+} \mathrm{NK}$ cells $(51.52 \%)$ remained lower than normal, whereas most patients showed normal levels of IL-2 (100\%), IL-4 (80.88\%), IL-6 (79.41\%), IL-10 (98.53\%), TNF- $\alpha$ (89.71\%), IFN- $\gamma(100 \%)$, and IL-17 (97.06\%). Compared to healthy controls, two-week postrecovery patients had significantly lower absolute numbers of total lymphocytes, $\mathrm{CD}^{+} \mathrm{T}$ cells, $\mathrm{CD}^{+} \mathrm{T}$ cells, $\mathrm{CD}^{+} \mathrm{T}$ cells, $\mathrm{CD} 19^{+} \mathrm{B}$ cells, and $\mathrm{CD} 56^{+} \mathrm{NK}$ cells, along with significantly higher levels of IL-2, IL-4, IL-6, IL-10, TNF- $\alpha$, IFN- $\gamma$, and IL-17. Among postrecovery patients, T cells, particularly $\mathrm{CD}^{+} \mathrm{T}$ cells, were positively correlated with $\mathrm{CD} 19^{+} \mathrm{B}$ cell counts. Additionally, $\mathrm{CD} 8^{+} \mathrm{T}$ cells were positively correlated with CD4 ${ }^{+}$T cells and IL-2 levels, and IL- 6 positively correlated with TNF- $\alpha$ and IFN- $\gamma$. These correlations were not observed in healthy controls. By ROC curve analysis, postrecovery decreases in lymphocyte subsets and increases in cytokines were identified as independent predictors of rehabilitation efficacy. These findings indicate that the immune system gradually recovers following COVID-19 infection; however, the sustained hyperinflammatory response for more than 14 days suggests a need to continue medical observation following discharge from the hospital. Longitudinal studies of a larger cohort of recovered patients are needed to fully understand the consequences of the infection.

\section{Introduction}

Since December 2019, severe cases of pneumonia have been reported in Wuhan, Hubei Province, China, and the disease has since spread rapidly throughout China and to overseas countries [1]. The causative virus was identified as a new Betacoronavirus, which was officially named severe acute respiratory syndrome coronavirus 2 (SARS-CoV-2), with the accompanying pneumonia referred to as coronavirus disease 2019 (COVID-19) [2]. By taking a series of preventive control and medical treatment measures, the rise of the epidemic within China has been contained to a certain extent [3]. In
mid-April 2020, the World Health Organization announced that approximately $1,914,916$ people were infected with the disease globally, with 123,010 deaths, and 501,758 people recovered [4]. Although patients can recover from the infection, some of the side effects may have a significant impact on recovered patients in the future. It is therefore imperative to understand the possible outcomes of COVID-19 recovered patients and determine if they are at higher risk of other detrimental illnesses using longitudinal analyses. Moreover, it is necessary to follow-up with these recovered patients and perform comprehensive assessments for appropriate management of their physical and psychological health [4]. 
Upon SARS-CoV-2 infection, the immune system carries out an immune response to defend against the virus. At present, a series of studies regarding the immune status and prognosis of patients with COVID-19 have been done $[5,6]$. Some of these studies focused on profiling cytokines in the peripheral blood of hospitalized patients with COVID-19, with one study reporting a significant increase in interleukin(IL-) 6 and IL-10 in patients with severe cases of COVID-19 [5]. However, the long-term consequences in patients who recovered and were discharged are still unknown. Lymphocytes play a critical role in maintaining immune function. Recent studies have observed that the levels of lymphocytes in patients with COVID-19 often decrease [5], but characteristics of lymphocyte subsets in patients who recover remain unknown. In this study, we aimed to detect lymphocyte subsets and cytokines in peripheral blood from patients who have recovered from COVID-19 to explore the immune status of these patients. This may have clinical value, by aiding in retrospective diagnoses and prognostic assessments of patients during the rehabilitation period and providing a quantitative basis for intervention.

\section{Materials and Methods}

2.1. Materials. From February 2020 to March 2020, we enrolled a total of 68 patients who were previously infected with SARS-CoV-2. These patients had been confirmed to be positive for SARS-CoV-2 nucleic acid by real-time fluorescent RT-PCR. All patients had been treated in hospital and then discharged when physical indices were in line with the discharge standards based on the national "Diagnosis and Treatment Protocol for Novel Coronavirus Pneumonia (Trial Version 7)" [7]. After two weeks of isolation, these patients were regarded as completely recovered, with no SARS-CoV-2 remaining in the body and a negative nucleic acid detection test.

In addition, we recruited subjects who had undergone physical examination in the Health Examination Center of The First Hospital of Shanxi Medical College during April 2020. These subjects were used as healthy controls (HCs) from whom serum samples were collected after obtaining informed consent. All recruited subjects including twoweek postrecovery patients and HC completed a questionnaire including questions regarding disease history, prescribed and over-the-counter medication, presence of fever, allergy, and eczema, and a general question concerning subjective health. Demographic data included diet, exercise status, ethnicity, and body mass index which were recorded. Patients were excluded if they had a history of illness including acute or chronic infections, hepatobiliary diseases, hematological diseases, urinary system diseases, nutrition and metabolism diseases, rheumatic diseases, endocrine diseases, circulatory system diseases, muscle trauma, hypertension, obesity (defined in this study as weight that is $10 \%$ more than the average weight of the reference population with the same sex and height), or malnutrition. Further, the included patients were excluded if they fulfilled any of the following testing criteria: positive in hepatitis B surface antigen, hepatitis $\mathrm{C}$ virus antibodies, or human immunodeficiency virus antibodies; creatinine above $120 \mu \mathrm{mol} / \mathrm{L}$, creatine kinase above $500 \mathrm{U} / \mathrm{L}$, uric acid above $475 \mu \mathrm{mol} / \mathrm{L}$, glucose above $7.0 \mathrm{mmol} / \mathrm{L}$, or C-reactive protein above $12.0 \mathrm{mg} / \mathrm{L}$. In total, 68 recovered patients, including 48 males aged 21-49 years and 20 females aged $24-66$ years, along with $28 \mathrm{HCs}$, including 8 males aged 21-53 years and 20 females aged 22-53 years, were included.

This study was approved by the ethics committee of The First Hospital of Shanxi Medical University. Written informed consent was obtained from all patients.

2.2. Reagents. Cytokine detection reagents were provided by Jiangxi Saiji Biotechnology Limited Company (calibrator lot number: 20190801). Lymphocyte subset detection kits were from Beckman Coulter Incorporated (USA).

2.3. Sample Collection. Two milliliters $(\mathrm{mL})$ of venous blood was collected from all subjects into EDTA anticoagulation tubes, and four $\mathrm{mL}$ of venous blood was collected into goldtopped serum-separating tubes with separating gel and then centrifuged at 2000-3000 rpm for $5 \mathrm{~min}$ to obtain serum. Samples exhibiting hemolysis, jaundice, or high lipid levels were removed.

2.4. Lymphocyte Subset Detection. Two flow tubes were prepared for each sample and labeled A and B, respectively. Ten microliters $(\mu \mathrm{L})$ of each monoclonal antibody was added to tube A (CD45-FITC/CD4-RD1/CD8-ECD/CD3-PC5 antibody) or tube B (CD45-FITC/CD56-RD1/CD19ECD/CD3-PC5 antibody). A volume of $100 \mu \mathrm{L}$ of EDTAanticoagulated whole blood was then added to the corresponding flow tubes, and the tubes were vortexed and incubated at 23-28 centigrade for $20 \mathrm{~min}$ in the dark. Next, $1 \mathrm{~mL}$ of lysing solution was added to all tubes. After incubating the tubes at room temperature for an additional $20 \mathrm{~min}$ in the dark, samples were centrifuged at $200 \times g$ in a low-speed centrifuge for $5 \mathrm{~min}$, the supernatant was aspirated, and $2 \mathrm{~mL}$ of PBS was added to each tube. Samples were centrifuged again at $200 \times g$ for $5 \mathrm{~min}$, supernatant was aspirated, and $500 \mu \mathrm{L}$ of PBS was added. The samples were then analyzed by fluorescence-labeled flow cytometry on a DxFLEX flow cytometer (Beckman Coulter USA Limited Company).

2.5. Cytokine Detection. Venous blood samples were collected into tubes containing separating gel and centrifuged at 2000$4000 \mathrm{rpm}$ for $20 \mathrm{~min}$ to obtain serum for analysis. Seven cytokines including IL-2, IL-4, IL-6, IL-10, IL-17, TNF- $\alpha$, and IFN- $\gamma$ were detected by multiple microsphere flow immunofluorescence according to the manufacturer's instructions. After blood samples and the corresponding flow tubes were numbered from 1 to 27 , the captured microsphere mixture was centrifuged at $200 \times g$ in a low-speed centrifuge for $5 \mathrm{~min}$, and the supernatant was carefully aspirated. Microsphere buffer of the same volume as the supernatant was then added, and samples were mixed well on a whirlpool and incubated in the dark for $30 \mathrm{~min}$. Next, $25 \mu \mathrm{L}$ of the above incubated captured microsphere mixture, $25 \mu \mathrm{L}$ of centrifuged serum, and $25 \mu \mathrm{L}$ of fluorescent reagents were added to the corresponding flow tube, and all tubes were mixed well. After incubating at 23-28 centigrade for 2.5 hours in the dark, 
$1 \mathrm{~mL}$ of PBS was added into each flow tube. After centrifuging at $200 \times g$ for $5 \mathrm{~min}$, the supernatant was carefully aspirated, and $100 \mu \mathrm{L}$ of PBS was added to each flow tube. Fluorescent detection was then performed on a calibrated flow cytometer for each sample in sequence.

2.6. Statistics. All statistical analyses were performed using EXCEL (Microsoft) and SPSS Statistics version 21.0 software. Briefly, the data were inspected using scatter and distribution plots, outliers were removed following Dixon's rule, and normality was determined using the Shapiro-Wilk test. Continuous variables were expressed as mean $\pm \mathrm{SD}$, and the comparison between groups was analyzed by $t$-tests. Noncontinuous variables were expressed as median with interquartile range (IQR), and the comparison between groups was analyzed using nonparametric comparative tests. Correlation analysis results were expressed by Pearson or Spearman correlation coefficient, with a larger " $r$ " indicating a stronger linear correlation. $P<0.05$ was considered as statistically significant. Receiver operating characteristic (ROC) curve analyses were conducted to evaluate the probability of cytokine and lymphocyte subsets in predicting recovery efficacy.

\section{Results}

3.1. Baseline Data. The study population included 68 patients two weeks after recovering from COVID-19 with a mean age of $33.98 \pm 8.03$ and $28 \mathrm{HCs}$ with a mean age of $35.13 \pm 8.85$.

3.2. Detection of Lymphocyte Subsets. Due to the impact of the epidemic during the early stages of this study, it should be noted that the supply of reagents was insufficient. Thus, samples from only 33 of 68 postrecovery patients were analyzed. According to the results of each measurement, $\mathrm{CD}^{+} \mathrm{T}$ cells, $\mathrm{CD}^{+}{ }^{+} \mathrm{T}$ cells, $\mathrm{CD}^{+} \mathrm{T}$ cells, $\mathrm{CD} 19^{+} \mathrm{B}$ cells, $\mathrm{CD} 56^{+} \mathrm{NK}$ cells, and $\mathrm{CD}^{+} / \mathrm{CD}^{+} \mathrm{T}$ cells were divided into "below normal range," "within normal range," and "above normal range." The corresponding quantification of each lymphocyte subset and proportions in each of the aforementioned ranges were calculated, with the results shown in Table 1.

Among the 33 postrecovery patients, 22 (66.67\%) patients had total lymphocyte counts below the normal range, $9(27.27 \%)$ within the normal range, and $2(6.06 \%)$ above the normal range. Eighteen (54.55\%) patients had $\mathrm{CD}^{+} \mathrm{T}$ cell counts below the normal range, $12(36.36 \%)$ within the normal range, and 3 (9.09\%) above the normal range. Additionally, 18 (54.55\%) patients had $\mathrm{CD}^{+} \mathrm{T}$ cell counts below the normal range, 13 (39.39\%) within the normal range, and $2(6.06 \%)$ above the normal range. Furthermore, $27(81.82 \%)$ patients had $\mathrm{CD}^{+} \mathrm{T}$ cell counts below the normal range, $5(15.15 \%)$ within the normal range, and 1 (3.03\%) above the normal range. Twenty-three $(69.70 \%)$ patients had $\mathrm{CD}_{1} 9^{+} \mathrm{B}$ cell counts below the normal range, $9(27.27 \%)$ within the normal range, and 1 (3.03\%) above the normal range. Seventeen $(51.52 \%)$ patients had CD $56^{+}$ NK cell counts below the normal range, and $16(48.48 \%)$ patients were within the normal range. In addition, 29
(87.88\%) patients had $\mathrm{CD} 4^{+} / \mathrm{CD}^{+}$cell ratios within the normal range, and $4(12.12 \%)$ patients were above the range.

Among the $28 \mathrm{HCs}, 5$ (17.86\%) had total lymphocyte counts below the normal range, $18(64.28 \%)$ were within the normal range, and $5(17.86 \%)$ were above the normal range. Five (17.86\%) HCs had $\mathrm{CD}^{+} \mathrm{T}$ cell counts below the normal range, 19 (67.86\%) were within the normal range, and $4(14.28 \%)$ were above the normal range. Additionally, 5 (17.86\%) HCs had $\mathrm{CD}^{+} \mathrm{T}$ cell counts below the normal range, and $23(82.14 \%)$ were within the normal range. Four HCs (14.29\%) had $\mathrm{CD}^{+} \mathrm{T}$ cell counts below the normal range, $17(60.71 \%)$ were within the normal range, and 7 (25\%) were above the normal range. Moreover, 15 (53.57\%) HCs had $\mathrm{CD} 19^{+} \mathrm{B}$ cell counts below the normal range, 12 $(42.86 \%)$ were within the normal range, and $1(3.57 \%)$ was above the normal range. Seven $(25 \%) \mathrm{HCs}$ had $\mathrm{CD}^{+} 6^{+} \mathrm{NK}$ cell counts below the normal range, 17 (60.71\%) were within the normal range, and $4(14.29 \%)$ were above the normal range; $27(96.43 \%) \mathrm{HCs}$ had $\mathrm{CD}^{+} / \mathrm{CD}^{+}$cell ratios within the normal range, and $1(3.57 \%)$ was above normal.

3.3. Detection of Cytokines. Cytokines including IL-4, IL-6, IL-10, IL-17, TNF- $\alpha$, and IFN- $\gamma$ were divided into "within the normal range" and "above the normal range" according to various indicators. The corresponding concentration of each cytokine and proportions in each of the aforementioned ranges were calculated (Table 2 ).

Among the 68 postrecovery patients, all 68 (100\%) patients had IL-2 within the normal range. Fifty-five (80.88\%), 54 (79.41\%), and 67 (98.53\%) patients had IL-4, IL-6, and IL-10 within the normal range, respectively, and the remaining 13 (19.12\%), 14 (20.59\%), and 1 (1.47\%) patients were above normal for these cytokines. Moreover, $61(89.71 \%)$ patients had TNF- $\alpha$ within the normal range, and $7(10.29 \%)$ patients were above normal. All 68 (100\%) patients had IFN- $\gamma$ within the normal range. Sixty-six (97.06\%) patients had IL-17 within the normal range, and 2 (2.94\%) patients were above normal. Among the $28 \mathrm{HCs}$, all subjects had IL-2, IL-4, IL-6, IL-10, TNF- $\alpha$, IFN- $\gamma$, and IL-17 within the normal values.

3.4. Comparison of Lymphocyte Subsets and Cytokines. Interestingly, there were significant differences in the levels of total lymphocytes, $\mathrm{CD}^{+} \mathrm{T}$ cells, $\mathrm{CD}^{+} \mathrm{T}$ cells, $\mathrm{CD}^{+} \mathrm{T}$ cells, CD $19^{+}$B cells, CD $56^{+}$NK cells, IL-2, IL-4, IL-6, IL-10, TNF- $\alpha$, IFN $-\gamma$, and IL- 17 , while the $\mathrm{CD} 4^{+} / \mathrm{CD}^{+}$ratio showed no significant differences between postrecovery patients and HCs. These results are shown in Table 3 and Figure 1.

3.5. Correlation between Lymphocyte Subsets and Cytokines. Considering that we observed significant differences in cytokines and lymphocyte subsets between patients who recovered from COVID-19 and HCs, the correlations between the cytokines and lymphocyte subsets were analyzed.

In two-week postrecovery patients, $\mathrm{CD}^{+}{ }^{+} \mathrm{T}$ cells were positively correlated with $\mathrm{CD} 19^{+} \mathrm{B}$ cells $(P \leq 0.001)$, and $\mathrm{CD} 4^{+} \mathrm{T}$ cells were positively correlated with $\mathrm{CD} 19^{+} \mathrm{B}$ cells $(P \leq 0.001)$. For cytokines, IL-2 was positively correlated with 
TABLE 1: Detection results of lymphocyte subsets in two-week postrecovery patients and HCs (cases, \%).

\begin{tabular}{|c|c|c|c|c|c|c|c|c|c|c|c|c|c|c|}
\hline \multirow[t]{2}{*}{ Groups } & \multicolumn{2}{|c|}{$\begin{array}{c}\text { Total } \\
\text { lymphocyte }\end{array}$} & \multicolumn{2}{|c|}{$\mathrm{CD}^{+} \mathrm{T}$ cell } & \multicolumn{2}{|c|}{$\underset{\text { cell }}{\mathrm{CD}^{+} \mathrm{CD}^{+} \mathrm{T}}$} & \multicolumn{2}{|c|}{$\begin{array}{c}\mathrm{CD}^{+} \mathrm{CD}^{+} \mathrm{T} \\
\text { cell }\end{array}$} & \multicolumn{2}{|c|}{$\mathrm{CD} 19^{+} \mathrm{B}$ cell } & & \multicolumn{2}{|c|}{$\mathrm{CD} 4^{+} / \mathrm{CD}^{+}$} \\
\hline & $\mathrm{RP}$ & $\mathrm{HCs}$ & $\mathrm{RP}$ & $\mathrm{HCs}$ & $\mathrm{RP}$ & $\mathrm{HCs}$ & $\mathrm{RP}$ & $\mathrm{HCs}$ & 11 & $\mathrm{HCs}$ & $\mathrm{RP}$ & $\mathrm{HCs}$ & $\mathrm{D}$ & $\mathrm{HCs}$ \\
\hline & $\begin{array}{l}22 \\
6.67)\end{array}$ & $\begin{array}{c}5 \\
(17.86)\end{array}$ & $(54.55)$ & $\begin{array}{c}5 \\
(17.86)\end{array}$ & $\begin{array}{c}18 \\
(54.55)\end{array}$ & $\begin{array}{c}5 \\
(17.86)\end{array}$ & $\begin{array}{c}27 \\
(81.82)\end{array}$ & $\begin{array}{c}4 \\
(14.29)\end{array}$ & $\begin{array}{c}23 \\
(69.70)\end{array}$ & $\begin{array}{c}15 \\
(53.57)\end{array}$ & $\begin{array}{c}17 \\
(51.52)\end{array}$ & $\begin{array}{c}7 \\
(25.00)\end{array}$ & & $0(0)$ \\
\hline valu & $\begin{array}{l}9 \\
7.27)\end{array}$ & $\begin{array}{l}18 \\
54.28)\end{array}$ & $(36.36)$ & $\begin{array}{c}19 \\
(67.86)\end{array}$ & $\begin{array}{c}13 \\
39.39)\end{array}$ & $\begin{array}{c}23 \\
(82.14)\end{array}$ & $\begin{array}{c}5 \\
(15.15)\end{array}$ & $\begin{array}{c}17 \\
(60.71)\end{array}$ & $\begin{array}{c}9 \\
27.27)\end{array}$ & $\begin{array}{c}12 \\
(42.86)\end{array}$ & 1 & $\begin{array}{c}17 \\
(60.71)\end{array}$ & $\begin{array}{r}2 \\
(87\end{array}$ & $\begin{array}{r}27 \\
(96.43\end{array}$ \\
\hline $\mathrm{Abc}$ & $\begin{array}{c}2 \\
6.06)\end{array}$ & $\begin{array}{c}5 \\
17.86)\end{array}$ & $\begin{array}{c}3 \\
(9.09)\end{array}$ & $\begin{array}{c}4 \\
(14.28)\end{array}$ & $\begin{array}{c}2 \\
(6.06)\end{array}$ & $0(0)$ & $\begin{array}{c}1 \\
(3.03)\end{array}$ & $\begin{array}{c}7 \\
(25.00)\end{array}$ & $\begin{array}{c}1 \\
(3.03)\end{array}$ & $\begin{array}{l}1 \\
(3.57)\end{array}$ & $0(0)$ & $\begin{array}{c}4 \\
(14.29)\end{array}$ & $\begin{array}{c}4 \\
(12.12)\end{array}$ & $\begin{array}{c}1 \\
(3.57)\end{array}$ \\
\hline
\end{tabular}

RP: two-week postrecovery patients; HCs: healthy controls.

TABLE 2: Detection results of cytokines in two-week postrecovery patients and HCs (cases, \%).

\begin{tabular}{|c|c|c|c|c|c|c|c|c|c|c|c|c|c|c|}
\hline \multirow{2}{*}{ Groups } & \multicolumn{2}{|c|}{ IL-2 } & \multicolumn{2}{|c|}{ IL-4 } & \multicolumn{2}{|c|}{ IL-6 } & \multicolumn{2}{|c|}{ IL-10 } & \multicolumn{2}{|c|}{ TNF- $\alpha$} & \multicolumn{2}{|c|}{ INF- $\gamma$} & \multicolumn{2}{|c|}{ IL-17 } \\
\hline & $\mathrm{RP}$ & HCs & $\mathrm{P}$ & HCs & $\mathrm{RP}$ & HCs & $\mathrm{RP}$ & HCs & $\mathrm{RP}$ & $\mathrm{HCs}$ & $\mathrm{RP}$ & $\mathrm{HCs}$ & $\mathrm{RP}$ & $\mathrm{HCs}$ \\
\hline & $\begin{array}{c}68 \\
(100)\end{array}$ & $\begin{array}{c}28 \\
(100)\end{array}$ & $\begin{array}{c}55 \\
(80.88)\end{array}$ & $\begin{array}{c}28 \\
(100)\end{array}$ & $\begin{array}{c}54 \\
(79.41)\end{array}$ & $\begin{array}{c}28 \\
(100)\end{array}$ & $\begin{array}{c}67 \\
(98.53)\end{array}$ & $\begin{array}{c}28 \\
(100)\end{array}$ & $\begin{array}{c}61 \\
(89.71)\end{array}$ & $\begin{array}{c}28 \\
(100)\end{array}$ & $\begin{array}{c}68 \\
(100)\end{array}$ & $\begin{array}{c}28 \\
(100)\end{array}$ & $\begin{array}{c}66 \\
(97.06)\end{array}$ & $\begin{array}{c}28 \\
(100)\end{array}$ \\
\hline $\begin{array}{l}\text { Above normal values } \\
(n, \%)\end{array}$ & (0) & $0(0)$ & $\begin{array}{c}13 \\
(19.12)\end{array}$ & $0(0)$ & $\begin{array}{c}14 \\
(20.59)\end{array}$ & $0(0)$ & $\begin{array}{c}1 \\
(1.47)\end{array}$ & $0(0)$ & $\begin{array}{c}7 \\
(10.29)\end{array}$ & $0(0)$ & $0(0)$ & $0(0)$ & $\begin{array}{c}2 \\
(2.94)\end{array}$ & $0(0)$ \\
\hline
\end{tabular}

RP: two-week postrecovery patients; HCs: healthy controls.

TABLE 3: Comparison of lymphocyte subsets and cytokines between two-week postrecovery patients and HCs.

\begin{tabular}{|c|c|c|c|c|c|c|c|c|c|}
\hline \multirow{2}{*}{ Groups } & \multicolumn{4}{|c|}{ Lymphocyte subsets (per/ $\mu \mathrm{L}$ ) } & \multirow{2}{*}{ Groups } & \multicolumn{4}{|c|}{ Cytokines (pg/mL) } \\
\hline & $\mathrm{RP}(n=68)$ & HCs $(n=28)$ & $t / Z$ & $P$ & & $\mathrm{RP}(n=68)$ & HCs $(n=28)$ & $t / Z$ & $P$ \\
\hline Total lymphocyte & $1488 \pm 718$ & $2241 \pm 488$ & 4.85 & $<0.01$ & IL-2 & $0.31(0.14,0.80)$ & $0.14(0,0.14)$ & -4.27 & $<0.01$ \\
\hline $\mathrm{CD}^{+} \mathrm{T}$ cell & $1055 \pm 578$ & $1529 \pm 389$ & 3.80 & $<0.01$ & IL-4 & $1.27(0.70,2.56)$ & $0.61(0.33,0.70)$ & -5.09 & $<0.01$ \\
\hline $\mathrm{CD}^{+}{ }^{+} \mathrm{CD} 4^{+} \mathrm{T}$ cell & $545 \pm 317$ & $738 \pm 161$ & 3.07 & $<0.01$ & IL-6 & $2.98(2.11,4.47)$ & $1.36(0.97,1.94)$ & -5.23 & $<0.01$ \\
\hline $\mathrm{CD}^{+}{ }^{+} \mathrm{CD} 8^{+} \mathrm{T}$ cell & $314 \pm 170$ & $603 \pm 212$ & 5.92 & $<0.01$ & IL-10 & $2.01(1.52,2.47)$ & $1.18(0.90,1.38)$ & -5.35 & $<0.01$ \\
\hline $\mathrm{CD} 19^{+} \mathrm{B}$ cell & $129 \pm 77$ & $190 \pm 74$ & 3.14 & $<0.01$ & TNF- $\alpha$ & $0.92(0.67,3.00)$ & $0.43(0.09,0.64)$ & -6.25 & $<0.01$ \\
\hline $\mathrm{CD}^{2} 6^{+} \mathrm{NK}$ cell & $166(83,257)$ & $271(174,491)$ & -2.80 & $<0.01$ & INF- $\gamma$ & $0.70(0.34,1.05)$ & $0.13(0.00,0.34)$ & -5.00 & $<0.01$ \\
\hline $\mathrm{CD}^{+} / \mathrm{CD}^{+}$ & $1.55(1.09,2.03)$ & $1.36 \pm 0.50$ & -1.54 & 0.12 & IL-17 & $10.25 \pm 4.25$ & $5.07 \pm 3.81$ & -5.58 & $<0.01$ \\
\hline
\end{tabular}

RP: two-week postrecovery patients; HCs: healthy controls.

IL-4 $(P=0.020)$ and TNF- $\alpha(P=0.007)$, IL-4 was positively correlated with IL-10 $(P \leq 0.001)$ and IL-17 $(P=0.032)$, IL6 was positively correlated with TNF- $\alpha(P=0.002)$, and IL10 was positively correlated with IFN- $\gamma(P=0.001)$. These results are summarized in Tables 4 and 5, and heat maps are shown in Figures 2 and 3.

3.6. ROC Curve Analysis. ROC curve analyses were conducted to evaluate the probability of changes in cytokines and peripheral lymphocyte subsets in predicting rehabilitation efficacy (Figure 4-6). The area under the ROC curve (AUC) was 0.793 (95\% confidence interval (CI): $0.680-$ 0.906) for the total lymphocyte decrease, 0.769 (95\% CI: $0.649-0.890)$ for the $\mathrm{CD}^{+} \mathrm{T}$ cell decrease, 0.716 (95\% CI: 0.585-0.848) for the $\mathrm{CD}^{+} \mathrm{T}$ cell decrease, 0.887 (95\% CI: $0.798-0.976)$ for the $\mathrm{CD}^{+} \mathrm{T}$ cell decrease, 0.715 (95\% CI: $0.588-0.843$ ) for the $\mathrm{CD} 19^{+} \mathrm{B}$ cell decrease, 0.709 (95\% CI: $0.579-0.840)$ for the $\mathrm{CD}^{2} 6^{+} \mathrm{NK}$ cell decrease, and 0.315 (95\% CI: $0.180-0.450)$ for the $\mathrm{CD}^{+} / \mathrm{CD} 8^{+}$ratio decrease.
The AUC was 0.775 (95\% CI: $0.667-0.874)$ for the IL-2 increase, 0.830 (95\% CI: $0.750-0.910)$ for the IL-4 increase, 0.840 (95\% CI: $0.754-0.927$ ) for the IL-6 increase, 0.848 (95\% CI: $0.770-0.926)$ for the IL-10 increase, $0.906(95 \%$ CI: $0.849-0.963$ ) for the TNF- $\alpha$ increase, 0.824 (95\% CI: $0.739-0.909)$ for IFN- $\gamma$ increase, and 0.827 (95\% CI: $0.738-$ 0.917 ) for the IL-17 increase. The AUC was 0.900 (95\% CI: 0.818-0.982) for the decrease in overall peripheral lymphocyte subsets and 0.995 (95\% CI: 0.985-1.000) for the overall cytokine increase. These results are shown in Figures 4-6.

\section{Discussion}

The novel coronavirus is highly infectious, with the resulting disease having a poor prognosis and $2 \%$ mortality rate [8]. Most infected patients present with fever, fatigue, respiratory symptoms, gastrointestinal symptoms, and chest imaging changes. In severe cases, the virus may lead to acute respiratory distress syndrome, septic shock, multiple organ failure, 


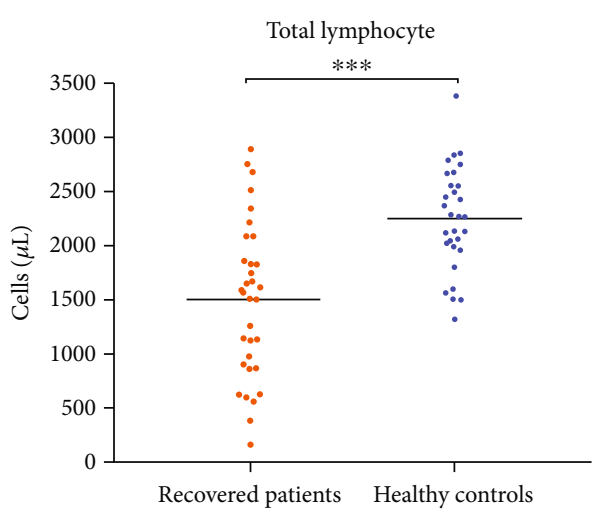

(a)

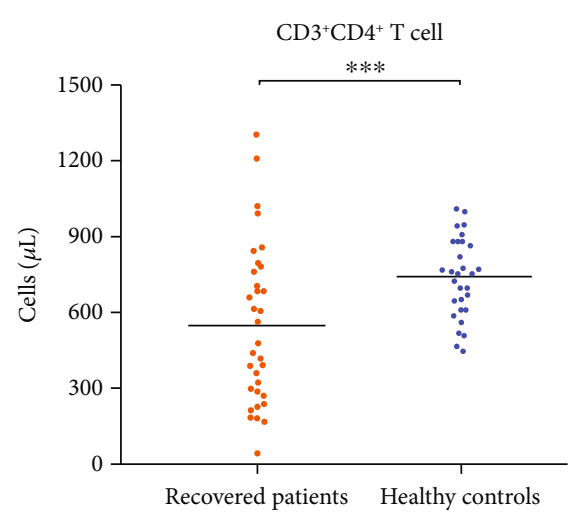

(c)

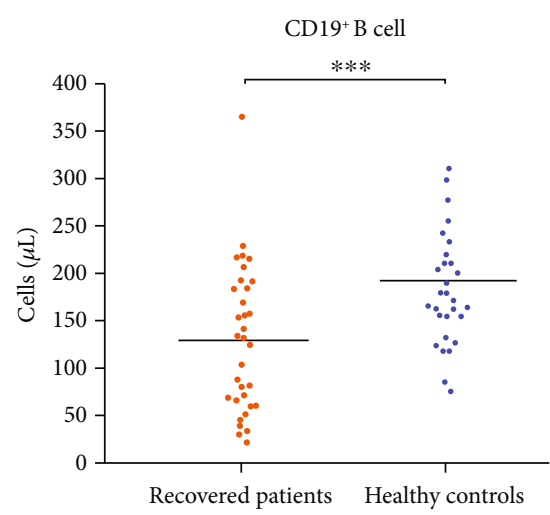

(e)

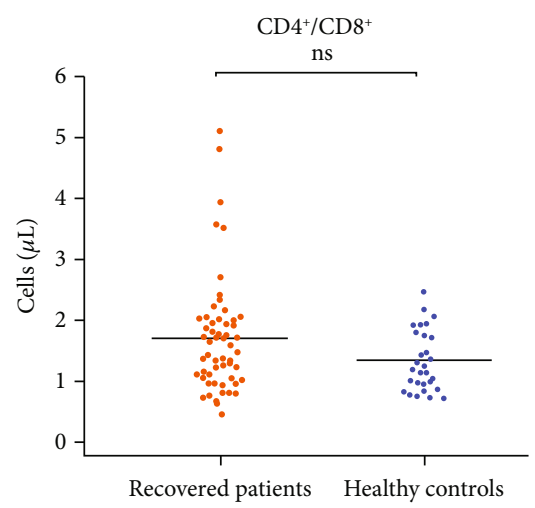

(g)

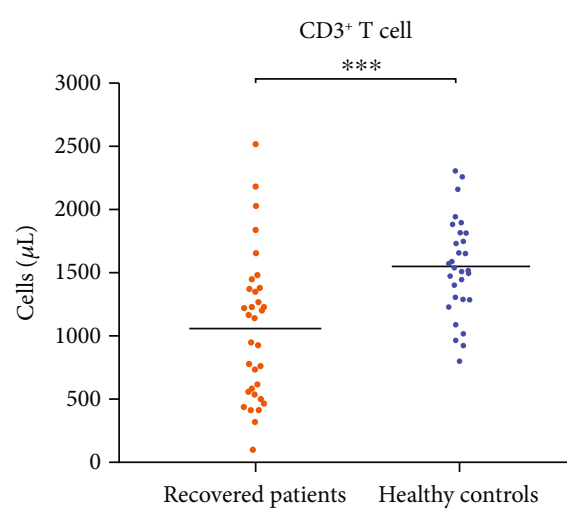

(b)

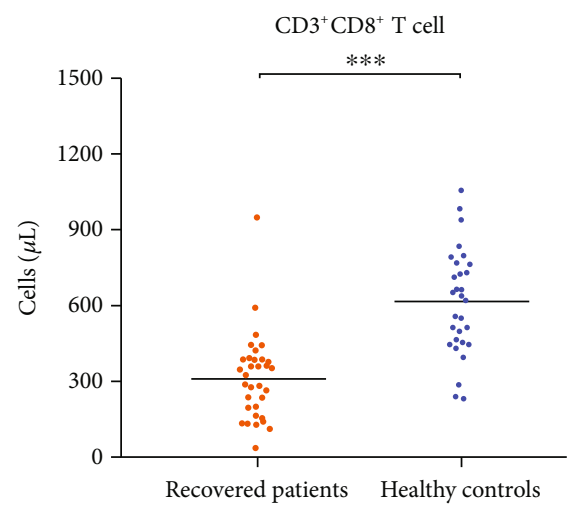

(d)

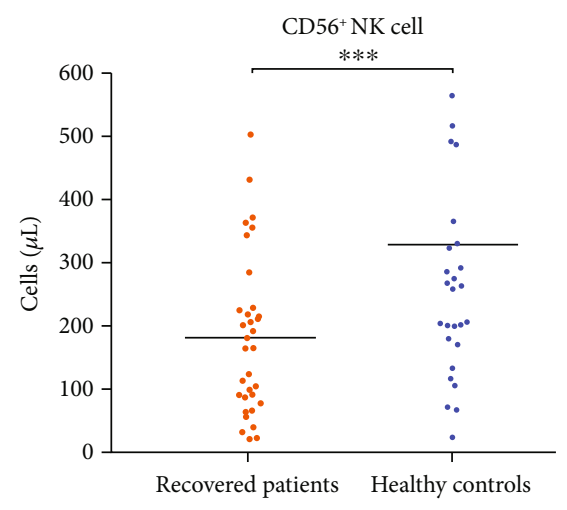

(f)

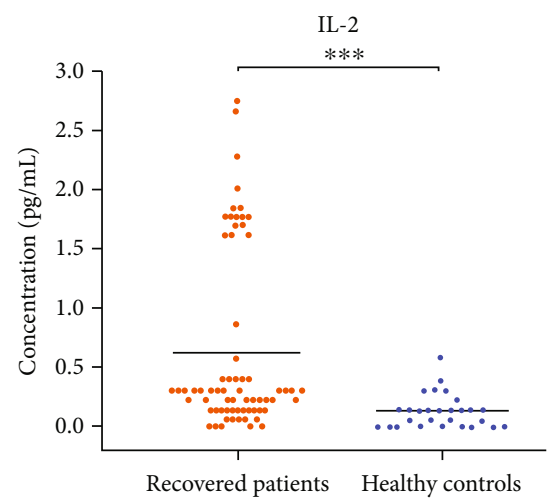

(h)

Figure 1: Continued. 


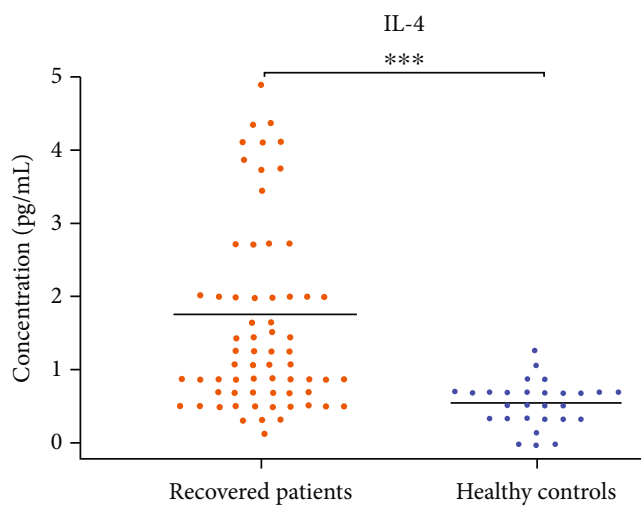

(i)

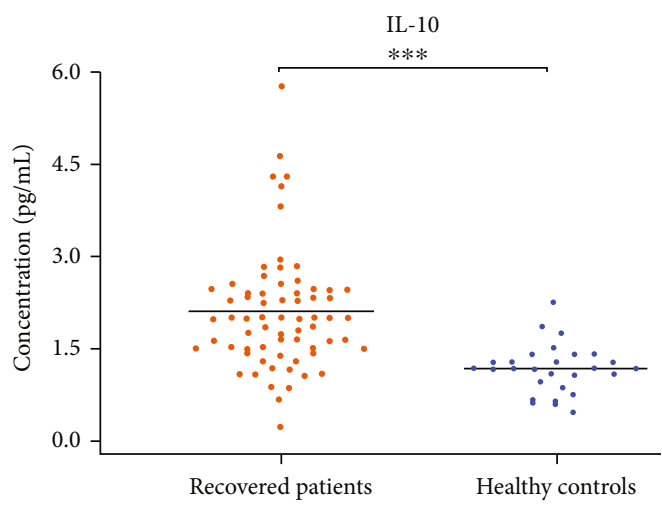

$(\mathrm{k})$

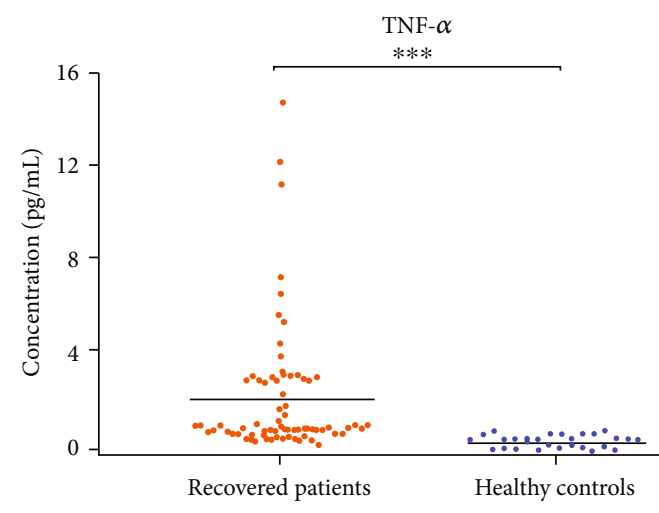

$(\mathrm{m})$

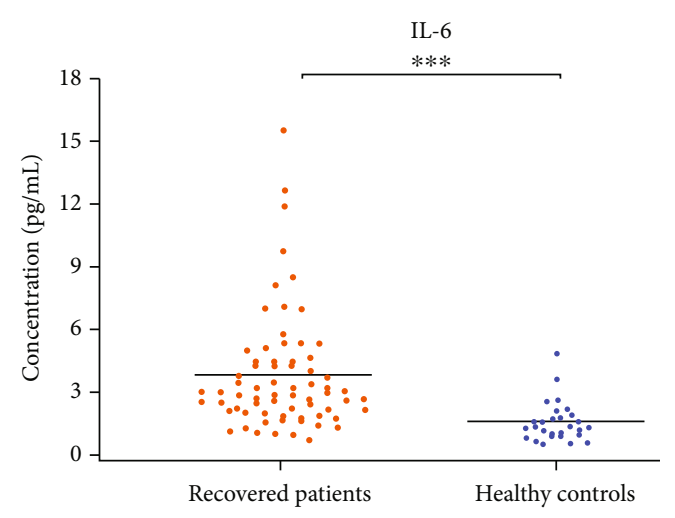

(j)

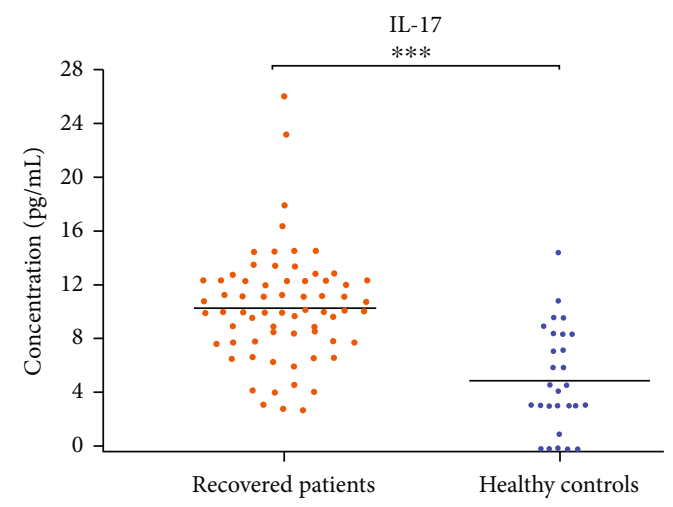

(l)

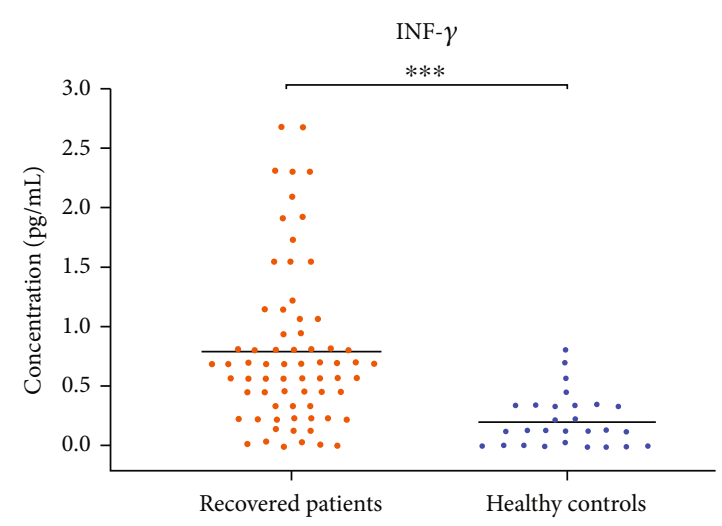

(n)

FIGURE 1: Comparison of lymphocyte subsets and cytokines between two-week postrecovery patients and HCs. Individual data are presented as dots. The absolute numbers of (a) total lymphocyte, (b) $\mathrm{CD}^{+} \mathrm{T}$ cell, (c) $\mathrm{CD}^{+} \mathrm{CD} 4^{+} \mathrm{T}$ cell, (d) $\mathrm{CD} 3^{+} \mathrm{CD} 8^{+} \mathrm{T}$ cell, (e) $\mathrm{CD} 19^{+} \mathrm{B}$ cell, (f) $\mathrm{CD}^{+} 6^{+} \mathrm{NK}$ cell, and (g) $\mathrm{CD}^{+} / \mathrm{CD}^{+}$in the peripheral blood of recovered patients (red dot) and HCs (blue dot) were analyzed. The concentrations of (h) IL-2, (i) IL-4, (j) IL-6, (k) IL-10, (l) TNF- $\alpha$, (m) IFN- $\gamma$, and (n) IL-17 in the serum of recovered patients (red dot) and healthy controls (blue dot) were analyzed. ${ }^{* * *} P \leq 0.001$; ns: not significant.

or even death [2]. It has been shown that following coronavirus infections, immune-related signaling pathways such as the toll-like receptor and retinoic acid-inducible gene-I-like receptor signaling pathways can affect the function of immune cells, such as T cells, B cells, and dendritic cells, inducing the production of a large number of Th17-related cytokines, which can further lead to dysfunction of the innate and adaptive immune systems [9]. It has been also shown that targeting the microenvironment and epigenome of the infected organism to regulate relevant immune pathways is an effective strategy to treat coronavirus infections [10-13]. However, the lack of knowledge regarding the impact of COVID-19 on the immune system remains a critical issue due to its rapid spread and the shortage of specific therapies [14]. In this study, we characterized lymphocyte subsets and cytokines in the peripheral blood of patients two weeks after recovering from COVID-19 infections. Our observed results may explain why some patients fell sick after being discharged; thus, we suggest that the current criteria for hospital discharge should be reevaluated. 


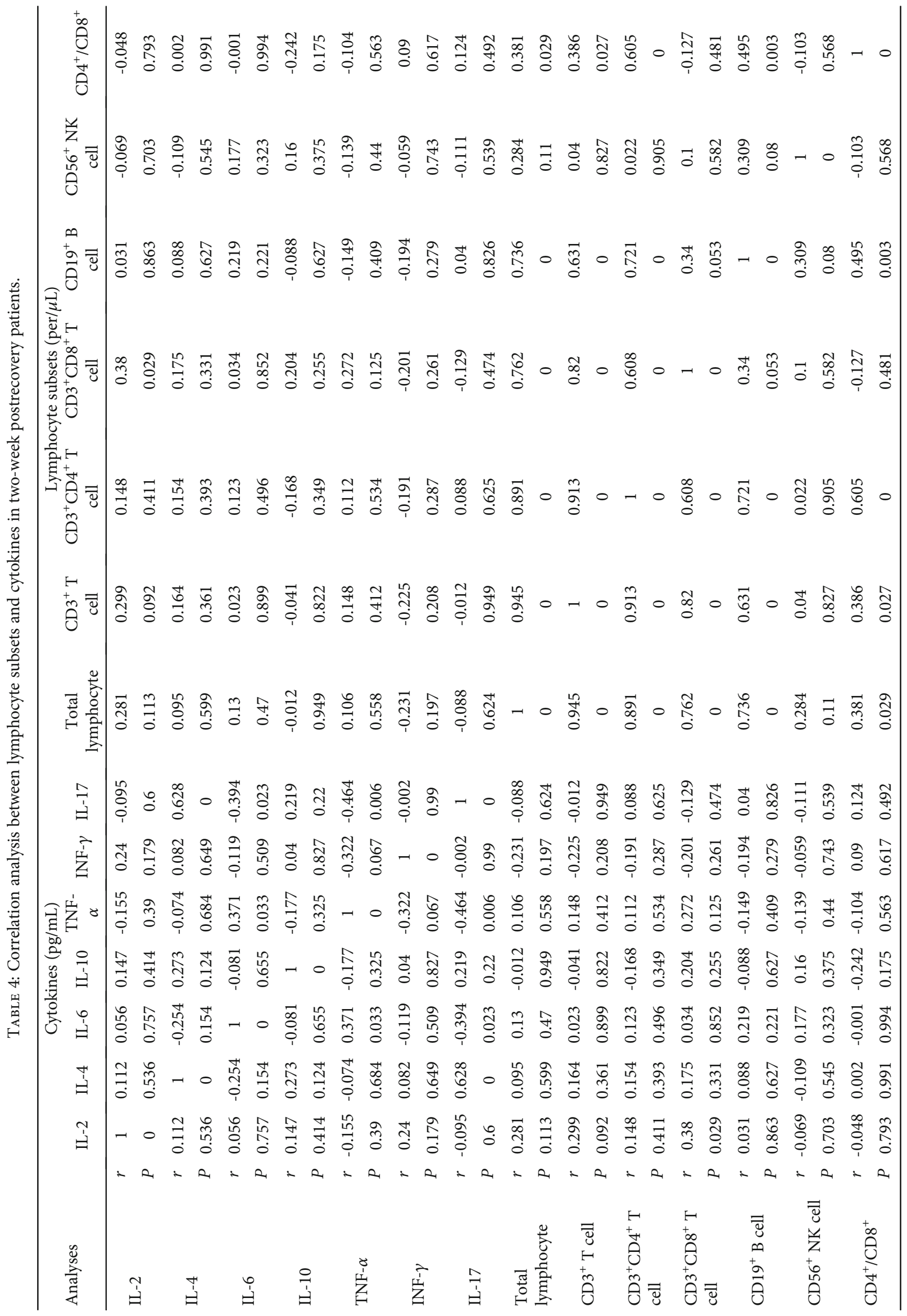




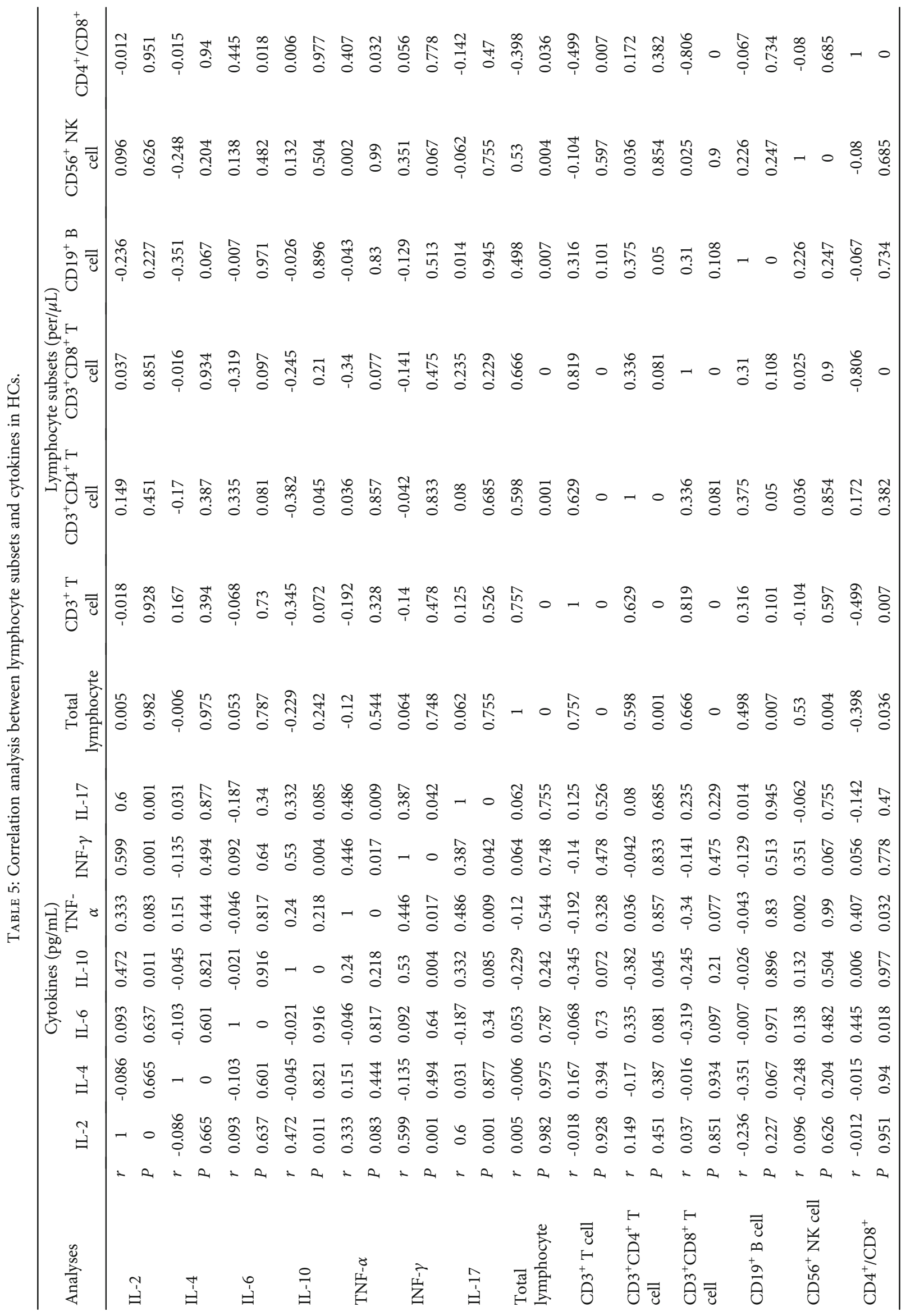




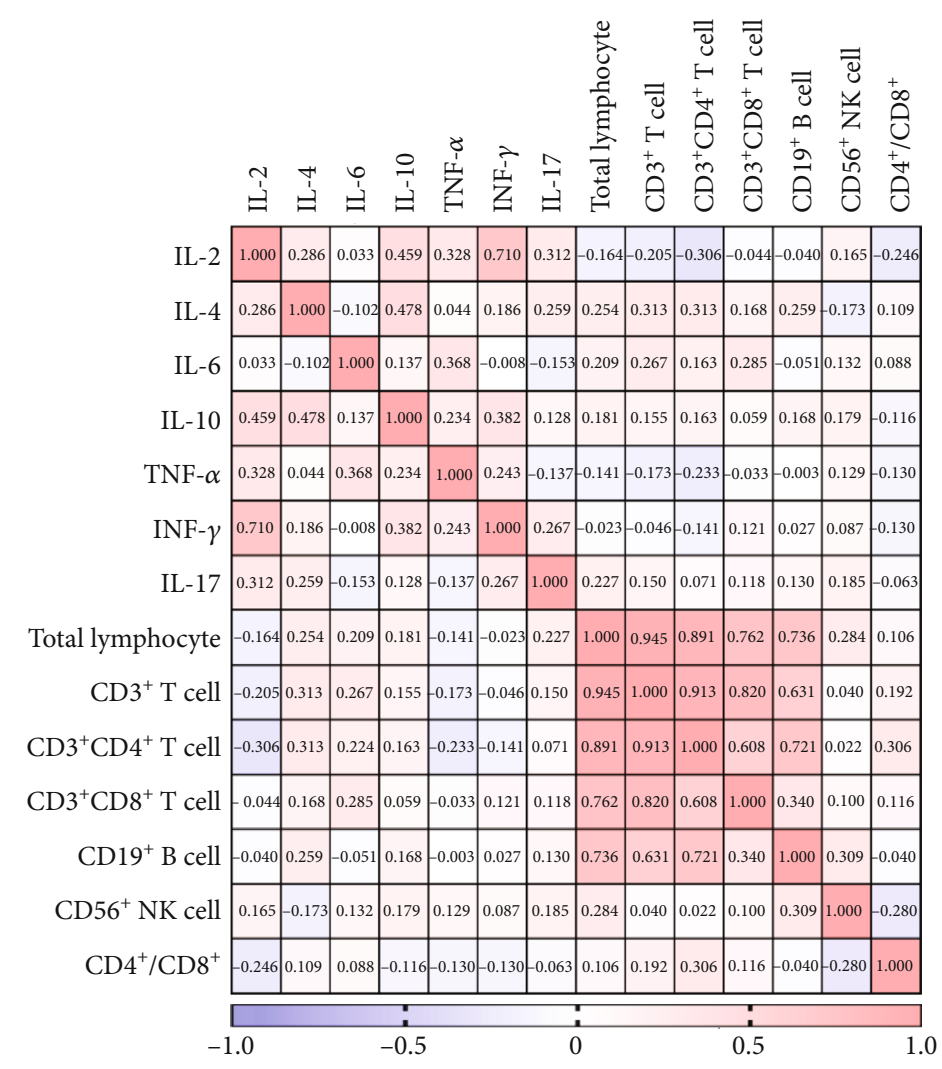

FIGURE 2: Correlation analysis was performed by R package to identify correlated variables among two-week postrecovery patients and described by correlation heat map. The red color represents positive correlation, the blue represents negative correlation, and the number in each grid represents correlation coefficient.

Lymphocytes play critical roles in viral clearance during respiratory infections. Previous studies indicated that SARS-CoV-2 infections could lead to dysregulation of the levels of lymphocyte subsets, by showing that the absolute counts of $\mathrm{CD}^{+} \mathrm{T}$ cells, CD4 ${ }^{+} \mathrm{T}$ cells, $\mathrm{CD} 8^{+} \mathrm{T}$ cells, CD $19^{+}$ $\mathrm{B}$ cells, and $\mathrm{CD}^{2} 6^{+} \mathrm{NK}$ cells were reduced in patients with COVID-19 [2, 5]. This suggests that the coronavirus may destroy many immune cells, thereby inhibiting the body's cellular immunity. Moreover, with disease improvement, the levels of total lymphocytes, $\mathrm{CD}^{+} \mathrm{T}$ cells, and $\mathrm{B}$ cells increased [5]. In our study, we found that in 33 postrecovery patients, most of them still exhibited lower than normal levels of total lymphocytes, total $\mathrm{T}$ cells, $\mathrm{CD} 4^{+} \mathrm{T}$ cells, $\mathrm{CD}^{+} \mathrm{T}$ cells, B cells, and NK cells. This is consistent with the results reported by Wen et al., which revealed that NK and $\mathrm{T}$ cells decreased in the peripheral blood of COVID-19 patients in both the early and late recovery stages [15]. Their study also demonstrated that cell-to-cell interactions may contribute to $\mathrm{T}$ cells and $\mathrm{B}$ cells, which may explain why the frequencies of peripheral blood lymphocytes gradually increased in recovering patients. In our study, compared to HCs, postrecovery patients displayed significantly lower absolute numbers of total lymphocytes, total $\mathrm{T}$ cells, CD $4^{+}$ T cells, CD8 ${ }^{+} \mathrm{T}$ cells, B cells, and NK cells. This was also consistent with the abovementioned study by Wen et al. [15], which found that compared to HCs, the absolute number of $\mathrm{CD}^{+} \mathrm{T}$ cells, $\mathrm{NK}$ cells, and $\mathrm{CD}^{+} \mathrm{T}$ cells decreased in
COVID-19 patients, especially in the recovery stage; however, they observed no significant changes in $\mathrm{CD}_{1} 9^{+} \mathrm{B}$ cell counts, unlike in our study. Possible reasons for this discrepancy may be the direct infection of lymphocytes by SARSCoV2, cytokine-mediated lymphocyte trafficking into infected tissues, or lymphocyte exhaustion in the peripheral blood. There may also be immune-mediated lymphocyte destruction as reported in other viral infections [15]. These potential hypotheses require further investigation. Since peripheral lymphocytes decrease following clinical cure and discharge, it is necessary to continue to observe and followup with COVID-19 patients to understand the long-term effects of SARS-CoV-2 on immune functions. In addition, due to the lack of clinical data in the early advanced stages of the disease, the alterations and functions of lymphocytes, particularly B cells, throughout the course of the disease need further study.

Previous studies have indicated that cytokine storms play an important role in severe COVID-19 cases [5, 6]. SARS$\mathrm{CoV}-2$ binds to alveolar epithelial cells, and then, the virus activates the innate and adaptive immune systems, resulting in the release of a large number of cytokines. In our study, we found that in 33 postrecovery patients, most of them showed normal levels of the tested cytokines. However, compared to HCs, patients who recovered from COVID-19 displayed significantly higher levels of cytokines. These results suggest that SARS-CoV-2 infection patients who recover will 


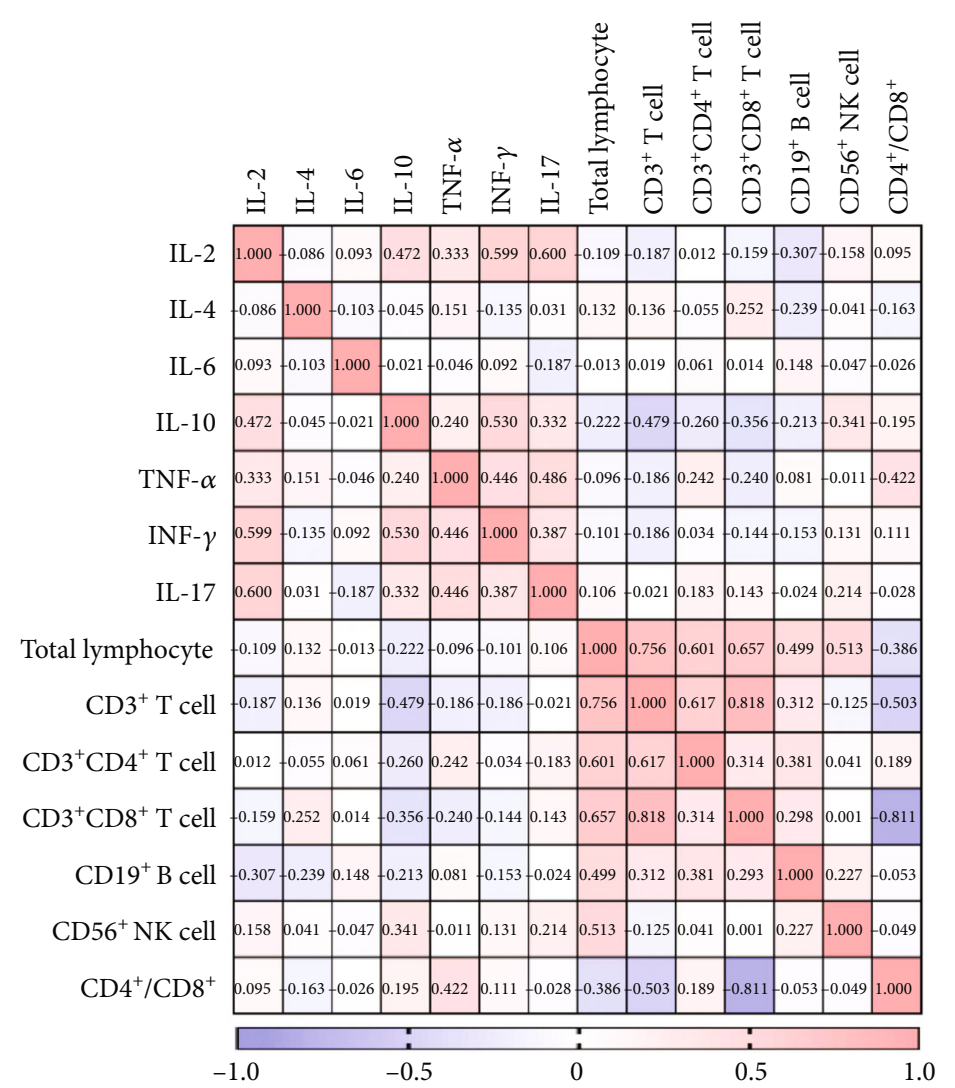

FIgURE 3: Correlation analysis was performed by R package to identify correlated variables among HCs and described by correlation heat map. The red color represents positive correlation, the blue represents negative correlation, and the number in each grid represents correlation coefficient.

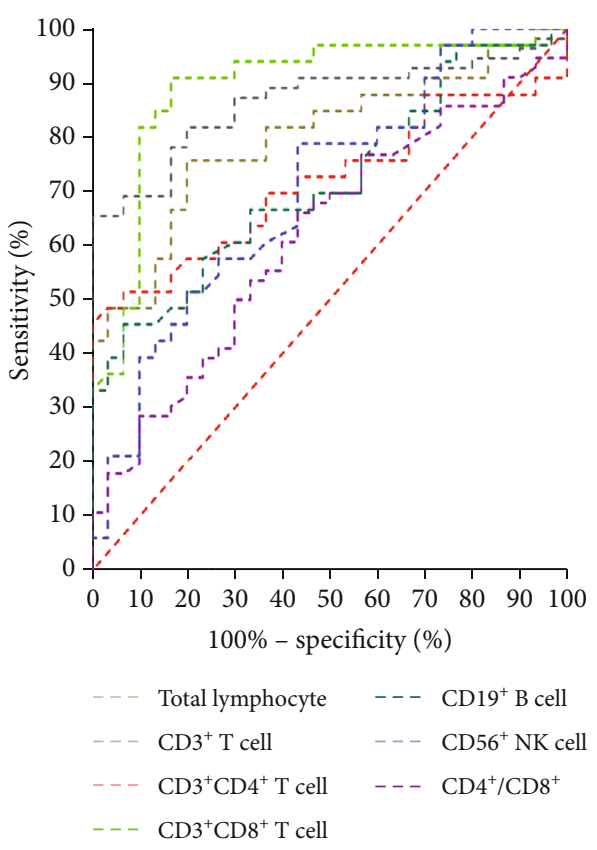

FIGURE 4: Receiver operating characteristic (ROC) curve analysis of postrecovery alteration of each lymphocyte subset in predicting rehabilitation efficacy. improve their antiviral ability within a certain period of time and then show a relatively active state of immunity. These alterations in cytokines were also found in the pneumonia caused by SARS-CoV-1. In a study by Fan et al., stimulation of peripheral blood mononuclear cells from patients four years after recovering from SARS-CoV using $\mathrm{S}$ peptides resulted in significantly higher levels of IFN- $\gamma$ production. However, studies characterizing cytokines from patients after recovering from SARS-CoV-2 infections remain limited and require further investigation.

Memory $\mathrm{T}$ cells consist of both $\mathrm{CD} 4^{+}$and $\mathrm{CD} 8^{+} \mathrm{T}$ cells that can rapidly acquire effector functions to eliminate infected cells and secrete cytokines that inhibit replication of pathogens and regulate immune responses. After stimulation with specific antigens, memory $\mathrm{CD} 4^{+} \mathrm{T}$ cells differentiate into effector cells. Based on their cytokine production, $\mathrm{CD}^{+}{ }^{+} \mathrm{T}$ cells can be classified as T-helper (Th) 1 and Th2 cells. Th1 cells secrete IL-2, IFN- $\gamma$, and TNF- $\alpha$ and participate in the cellular immune response. On the other hand, Th2 cells secrete IL-4, IL-6, and IL-10 and enhance humoral immune responses [16]. Among postrecovery patients, but not $\mathrm{HCs}, \mathrm{T}$ cells, and especially $\mathrm{CD} 4^{+} \mathrm{T}$ cells, were positively correlated with B cell counts, and IL-2 was positively correlated with $\mathrm{CD}^{+} \mathrm{T}$ cell levels. The study by Wen et al. reported that in COVID-19 patients, T cell-B cell interactions induce $T$ cells to produce IL-2, promoting the proliferation of $\mathrm{B}$ cells, which may explain the correlation between $\mathrm{T}$ and $\mathrm{B}$ 


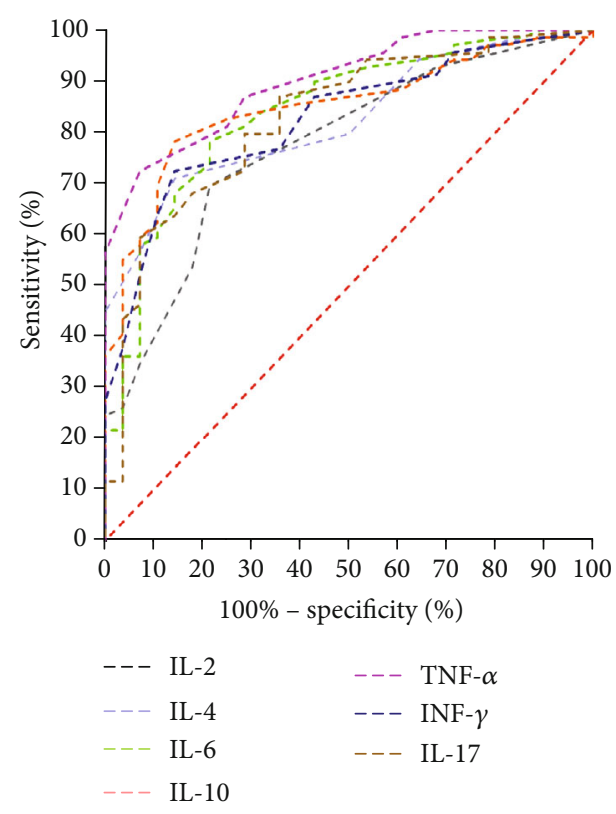

FIGURE 5: Receiver operating characteristic (ROC) curve analysis of postrecovery alteration of each cytokine in predicting rehabilitation efficacy.

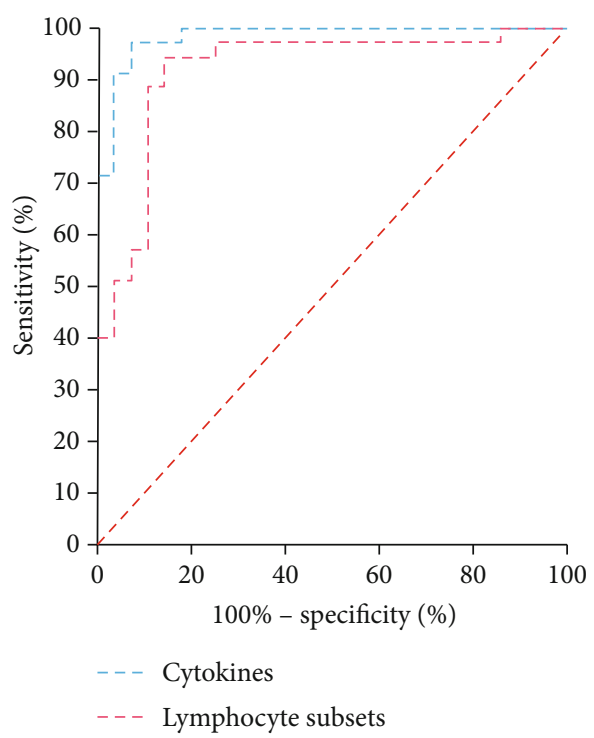

FIGURE 6: Receiver operating characteristic (ROC) curve analysis of post- recovery alteration of overall lymphocyte subsets and cytokines in predicting rehabilitation efficacy.

cells [15]. Unlike in HCs that showed no correlations, among patients who recovered from COVID-19, CD $4^{+} \mathrm{T}$ cells were positively correlated with $\mathrm{CD}^{+} \mathrm{T}$ cell counts. Wen et al.'s study characterized $\mathrm{T}$ and $\mathrm{NK}$ cell responses in the blood of recovered COVID-19 patients and showed that $\mathrm{CD} 4^{+} \mathrm{T}$ cells were the main participants in combating the infection and clonally expanded $\mathrm{CD}^{+} \mathrm{T}$ cells in the peripheral blood help control the spread of the virus [15]. Additionally, among postrecovery patients, IL-6 was positively correlated with TNF- $\alpha$ and IFN- $\gamma$. This was consistent with a study by Hunter and Jones, who demonstrated that the main activa- tors of IL- 6 expression are TNF- $\alpha$ and IL- $1 \beta$ [17]. In combination with a separate study, which reported that patients with severe cases of COVID-19 showed increases in IL-6 and IFN- $\gamma$ [6], we propose the hypothesis that IL-6 and IFN- $\gamma$ can be independent predictors for rehabilitation efficacy. This hypothesis could provide valuable insight into the cellular immune response in patients who recovered from SARS-CoV-2 and for the design of vaccines against SARSCoV-2.

In combination with the above findings, patients who recovered from COVID-19 infections had a concomitant significant decrease in lymphocyte subsets and increase in serum cytokines. ROC curve analyses identified the postrecovery decrease in lymphocyte subsets and the increase of cytokines as independent predictors for rehabilitation efficacy. Together, the recovery of immune function might be a reliable indicator of rehabilitation. By combining the peripheral cell counts and the secreted cytokines, we can evaluate the immune function of convalescent patients more effectively.

There are some limitations in this study. Firstly, due to the lack of clinical data during the early infection stage, continuous observational data from the same cases were absent, and potential influence by early events was not considered. Secondly, the sample size was relatively small in comparison with Wuhan where the disease originated, which may have some impact on the statistical results. In future experiments, we will conduct follow-up studies in the patients who recovered from COVID-19 and determine a quantitative basis for intervention of rehabilitation measures. This will help treat the diseases at an earlier stage by promoting medical intervention in a timely manner. Moreover, it may be beneficial to analyze if a particular population has an added immunological advantage while combating the virus.

\section{Conclusions}

In the present study, we applied flow cytometry to comprehensively characterize changes in circulating lymphocyte subsets and cytokines in patients who have recovered from COVID-19, as an assessment of their immune status following discharge. The results of both lymphocyte subsets and cytokines indicated that the immune system gradually recovers; however, the sustained hyperinflammatory response lasting more than 14 days following discharge suggests the need for continued medical observation after patients are discharged from the hospital. Longitudinal studies of recovered patients in a larger cohort might help to better understand the consequences of the disease.

\section{Data Availability}

The data are stored in the laboratory database.

\section{Conflicts of Interest}

The authors declare that there are no conflicts of interest regarding the publication of this paper. 


\section{Acknowledgments}

This work was financially supported by the Shanxi Province Social Development Program (No. 202003D31014/GZ).

\section{References}

[1] H. Lu, C. W. Stratton, and Y. W. Tang, "Outbreak of pneumonia of unknown etiology in Wuhan, China: the mystery and the miracle," Journal Of Medical Virology, vol. 92, no. 4, pp. 401-402, 2020.

[2] C. L. Huang, Y. M. Wang, X. W. Li et al., "Clinical features of patients infected with 2019 novel coronavirus in Wuhan, China," The Lancet, vol. 395, no. 10223, pp. 497-506, 2020.

[3] P. F. Tang, Z. Y. Hou, X. B. Wu et al., "Expert consensus on management principles of orthopedic emergency in the epidemic of coronavirus disease 2019," Chinese Medical Journal, vol. 133, no. 9, pp. 1096-1098, 2020.

[4] V. Balachandar, I. Mahalaxmi, M. Subramaniam et al., "Follow-up studies in COVID-19 recovered patients - is it mandatory?," Science of The Total Environment, vol. 729, no. 139021, aritcle 32360909, 2020

[5] J. Liu, S. Li, J. Liu et al., "Longitudinal characteristics of lymphocyte responses and cytokine profiles in the peripheral blood of SARS-CoV-2 infected patients," EBioMedicine, vol. 55, no. 102763, article 32361250, 2020.

[6] C. Zhang, Z. Wu, J. W. Li, H. Zhao, and G. Q. Wang, "Cytokine release syndrome in severe COVID-19: interleukin-6 receptor antagonist tocilizumab may be the key to reduce mortality," International Journal Of Antimicrobial Agents, vol. 55, no. 5, article 32234467, 2020.

[7] J. Y. Zhao, J. Y. Yan, and J. M. Qu, "Interpretations of "Diagnosis and Treatment Protocol for Novel Coronavirus Pneumonia (Trial Version 7)"," Chinese Medical Journal, vol. 133, no. 11, pp. 1347-1349, 2020.

[8] N. Zhu, D. Y. Zhang, W. L. Wang et al., "A novel coronavirus from patients with pneumonia in China, 2019," The New England Journal Of Medicine, vol. 382, no. 8, pp. 727-733, 2020.

[9] E. Kinder and V. Thiel, "To sense or not to sense viral RNA-essentials of coronavirus innate immune evasion," Current Opinion In Microbiology, vol. 20, pp. 69-75, 2014.

[10] L. L. Dickey, C. L. Worne, J. L. Glover, T. E. Lane, and R. M. O'Connell, "MicroRNA-155 enhances $\mathrm{T}$ cell trafficking and antiviral effector function in a model of coronavirus-induced neurologic disease," Journal Of Neuroinflammation, vol. 13, no. 1 , p. $240,2016$.

[11] A. Schäfer and R. Baric, "Epigenetic landscape during coronavirus infection," Pathogens, vol. 6, no. 1, p. 8, 2017.

[12] L. Morales, J. C. Oliveros, R. Fernandez-Delgado, B. R. tenOever, L. Enjuanes, and I. Sola, "SARS-CoV-encoded small RNAs contribute to infection-associated lung pathology," Cell Host Microbe, vol. 21, no. 3, pp. 344-355, 2017.

[13] M. Poppe, S. Wittig, L. Jurida et al., "The NF- $\kappa$ B-dependent and -independent transcriptome and chromatin landscapes of human coronavirus 229E-infected cells," PLoS Pathogens, vol. 13, no. 3, article e1006286, 2017.

[14] A. C. Walls, Y. J. Park, M. A. Tortorici, A. Wall, A. T. McGuire, and D. Veesler, "Structure, function, and antigenicity of the SARS-CoV-2 spike glycoprotein," Cell, vol. 181, no. 2, pp. 281-292.e6, 2020.
[15] W. Wen, W. Su, H. Tang et al., "Immune cell profiling of COVID-19 patients in the recovery stage by single-cell sequencing," Cell Discovery, vol. 6, no. 1, article 32377375, 2020.

[16] R. Okada, T. Kondo, F. Matsuki, H. Takata, and M. Takiguchi, "Phenotypic classification of human $\mathrm{CD} 4^{+} \mathrm{T}$ cell subsets and their differentiation," International Immunology, vol. 20, no. 9, pp. 1189-1199, 2008.

[17] C. A. Hunter and S. A. Jones, "IL-6 as a keystone cytokine in health and disease," Nature Immunology, vol. 16, no. 5, pp. 448-457, 2015. 